\section{Net disagreement}

\section{Washington}

THE news that the fleet of North Korean fishing boats arrested last month by the Soviet Union for illegal driftnet fishing close to the Kamchatka Peninsula was actually crewed by Japanese fishermen has caused a serious diplomatic incident. And it has strengthened US demands for a total international ban on the use of driftnet fishing. Even though Japan has no diplomatic relations with North Korea, Japanese driftnet fishermen made a deal with a group of North Korean fishermen in the hope of avoiding the high charges levied by the Soviet Union on Japanese boats fishing for salmon in the area.

To some US congressmen the incident is evidence of the how far fishermen will go to bend the rules governing the use of driftnets. These multiple $5-10 \mathrm{~km}$-long fine nylon structures are being blamed for destroying Pacific fisheries and indiscriminately stripping the seas of all living creatures. In response the US Senate Commerce committee reauthorized the Magnuson Act, which originally established the 200-mile Exclusive Economic Zone and is reviewed every five years, with an additional clause intended to secure a permanent ban on driftnet use on the high seas. The act has already passed the House of Representatives, and is expected to go to the Senate later this year.

No profit came to the Japanese fishermen from their deal with the North Koreans. Although, according to the Asahi Shinbun newspaper, the fishermen had hoped to make money by gaining access to the North Korean quota of Soviet salmon in exchange for allowing the North Koreans use of Japanese boats and technical guidance. They discovered, on their arrest by Soviet vessels, that North Korea actually had no salmon quota under the Soviet-North Korean fishing agreement. A total of 169 Japanese fishermen on 12 boats were arrested.

The North Korean incident and the subsequent Senate action comes as an embarrassment to the Japanese government. Last winter Japan adopted a United Nations General Assembly resolution intended to impose a moratorium on the use of massive driftnets from 30 June 1992, except in cases where it can be proven that an appropriate resources management scheme will be effective. A moratorium would be bad news for Japan, which operates the world's largest fleet of driftnet ships - a total of 900 ships generating an income of $¥ 48$ thousand million ( $\$ 300$ million) a year.

To avoid the moratorium, the Japan Fisheries Agency has just begun a largescale research effort to see how seriously driftnet fishing affects the effective con- servation of marine creatures. At risk are not only commercial fish stocks (see Nature 342, 9; 2 November 1989), but also other species of fish, marine mammals and sea birds. The research is being conducted with the cooperation of US and Canadian observers and an interim report is expected to be delivered later this month.

"We can't say how much impact driftnet fishing has on the marine ecosystem now. We know that dolphins, turtles, young whales, and others are killed by the massive driftnet, some of them are endangered species. But to get information on the magnitude of the impact and predict the future, we must wait for the result of CZECHOSLOVAKIA

\section{Students terrorized}

Pilsen

ViETNAMESE students in Czechoslovakia say that they fear for their lives as increasing freedom has brought racism into the open. One group of students, from the electrical engineering college in Pilsen, wrote to President Vaclav Havel asking him to help protect them from skinheads who have terrorized them and attacked gypsies and Vietnamese workers. Havel responded by criticizing the "dark forces" in Czechoslovakia - meaning former Communists or other agitators intent on causing anarchy. Violence has increased everywhere, especially since the government emptied the prisons in an amnesty that was apparently not restricted to political prisoners.

University rector Jiri Holenda said that the Vietnamese students are right to be afraid, even though the violence has mostly

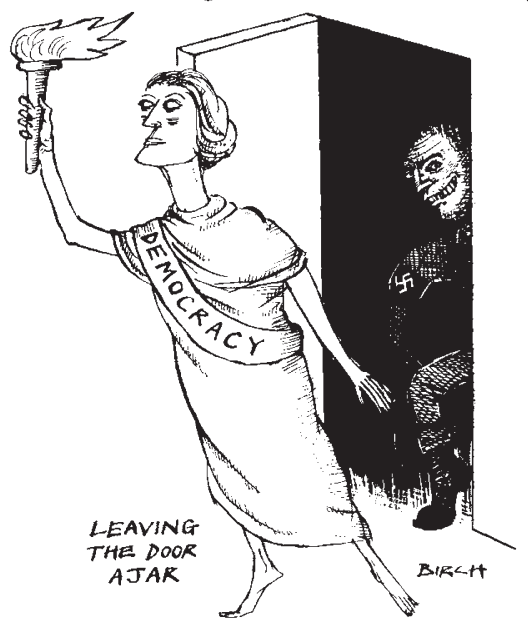

been directed at Vietnamese workers, who have a reputation for being active in the black market.

According to Radio Free Europe, there are more than 35,000 Vietnamese workers in Czechoslovakia. Their labour was made available by the Vietnamese government in repayment for Czechoslovak aid during the Vietnam War. this research," said Susan Smith, a researcher at the US National Marine Fisheries Service, which is collaborating on the project.

US congressional action comes far too soon for Japan, which would like to wait for more research data before considering its response to the UN moratorium. Japanese government officials say that increasing pressure for a total ban on driftnet fishing may bring more embarrassment for Japan. "Drastic pressure will produce a vicious circle - the stricter the regulations, the cleverer the loopholes [that will be found to avoid them]. This incident of 'piracy', which stains Japanese efforts to deal with the moratorium, is unlikely to be the last," predicted one government official.

Shigeko Segawa

\section{COCOM REFORMS \\ Easier access}

\section{Paris}

ThE 17-nation Coordinating Committee on Multilateral Export Controls (CoCom) has agreed to redefine restrictions on the sale of technology to Warsaw Pact countries. The changes, adopted at a two-day meeting here last week, are the most significant since CoCom was set up in 1949 .

The move comes in response to political changes in Eastern Europe and pressure from Western industry. The reforms will mean that the current list of sensitive technologies will be replaced by a new "core list" by the end of this year. Fewer items will be controlled, but security on these will be much tighter.

The new core list will have eight categories ranging from electronic systems, advanced materials and lasers to avionics and computers. An industrial list of controlled technologies has also been cut dramatically -30 headings have been removed out of 116 .

In future, sales of computers operating at 250 megabytes per second will be allowed and there will be easier access to those operating at over 1,000 megabytes per second. Restrictions will also be eased in telecommunications technology and sales of precision machine tools.

Eastern bloc countries will not be equally affected by the new rules, while almost no restrictions will be applied to East Germany, the Soviet Union will benefit least. Preferential treatment is to be given to Poland, Hungary and Czechoslovakia.

Despite the freeing of restrictions, some technologies will continue to be carefully guarded. Last week US and British governments stepped in to veto proposals by two competing telecommunications firms US West Inc and British Telecom - to lay fibre optics cables stretching from Japan to Western Europe across the Soviet Union. The technology has military applications and is used in missile control.

Peter Coles 